\title{
Alternative Fuel Tanks for Pickups with Sidesaddle Tanks
}

\author{
Kennerly Digges \\ Automotive Safety Research Institute
}

\author{
Ed Fournier, Matthew Keown, Nicholas Shewchenko, Jim Kot
}

Biokinetics and Associates, Ltd.

Copyright (C) 2005 SAE International

\begin{abstract}
Seventeen full-scale crash tests were conducted to evaluate technologies to reduce the vulnerability of sidesaddle tanks on full size GM pickup trucks manufactured during the period 1973-1987. These vehicles were alleged by the U.S. Department of Transportation to be vulnerable in severe side impacts. The test program was intended to evaluate designs that would reduce vulnerability in all crash directions. The best test results were obtained by two strategies that relocated the tank to less vulnerable locations. The two locations were: (1) in the cargo bed (bed mounted tank) and (2) underneath the bed, ahead of the rear axle and between the frame rails (center-mounted tank). Tanks mounted in these locations were subjected to a series of crash tests that simulated severe front, side, rear and rollover crashes. The crash environment for these tests was more severe than required by FMVSS 301 "Fuel System Integrity". Designs were developed for the bed mounted tank and the center-mounted tank that survived the series of multi-directional crash tests with fuel leakage less than that permitted by the FMVSS 301 standard.
\end{abstract}

\section{INTRODUCTION}

In 1967 the National Highway Traffic Safety Administration (NHTSA) introduced the Federal Motor Vehicle Safety Standard (FMVSS) No. 301, "Fuel System Integrity" [NHTSA Part 571.301] to reduce deaths and injuries occurring from fires. Initially, the standard only applied to passenger cars. However, in 1977 light trucks were also included. The standard prescribes three full-scale tests, a frontal, rear and lateral impact, following which a maximum acceptable fuel leakage rate is specified. After the crash test, the vehicle is subjected to a $360^{\circ}$ roll, during which fuel leakage must be below specified levels. The frontal impact comprises directing the subject vehicle into a flatface, rigid barrier at a speed of $48.0 \mathrm{~km} / \mathrm{h}(30.0 \mathrm{mph})$. For both the rear and lateral test, an $1814 \mathrm{~kg}$ rigid-flatfaced, moving barrier impacts the stationary vehicle. The test speed is $48.0 \mathrm{~km} / \mathrm{h}(30.0 \mathrm{mph})$ for rear impacts and $32.0 \mathrm{~km} / \mathrm{h}$ (20.0 $\mathrm{mph})$ for side impacts. In each test configuration the fuel tank must be filled to $90 \%$ to $95 \%$ capacity.

The General Motors C/K full size pickup (10 to 30 series) model years spanning 1973 to 1987 employed a sidesaddle tank design in which the tank was mounted outside the vehicle's frame rails. Although the sidesaddle design was largely discontinued in the 1988 and later models, it persisted on a few configurations until 1991.

In December 1992, the NHTSA Office of Defects Investigation (ODI) opened an investigation to determine if certain 1970-1991 Chevrolet C/K pickups contained a safety related defect [ODI, 1994]. The ODI investigation was to determine whether these full size pickups posed an unreasonable risk to safety, related to the danger of fires following crashes, with primary focus on side impact crashes. Based on ODI testing and full-scale test data provided by GM, it was concluded that the C/K trucks, to which the 301 Standard applied, were in compliance. The ODI's analysis of 1979-1993 real-world accident data indicated that the incident of fatal side crashes involving fire was higher for the $\mathrm{C} / \mathrm{K}$ pickup trucks than for its competitors. However, the ODI concluded that fatal side-impact crashes involving fire were generally more severe than the crashes specified by the FMVSS 301 standard. Crash testing disclosed that the $\mathrm{C} / \mathrm{K}$ pickup fuel system exceeded the leakage requirements of the 301 standard when impacted in the side by a Chevrolet Caprice traveling at $80 \mathrm{~km} / \mathrm{h}$ (50 mph). Competitive pickup models were found to survive this test. Test dummies in the crashed pickups indicated that the $80 \mathrm{~km} / \mathrm{h}$ (50 mph) side impact by a Caprice produced injury measures that were below the requirements for the federal standard for side impact (FMVSS 214). For example, in a typical test the values for HIC, TTI and Pelvic G were 511, 34.1, and 50.2, respectively [Markusic, 1993].

On April 9, 1993, ODI recommended to General Motors a safety recall on GM pickup models with the tank mounted outside the frame rails [ODI, 1994]. Subsequent negotiation between $\mathrm{GM}$ and the 
Department of Transportation resulted in an administrative settlement in lieu of a recall. Under this March 7, 1995 settlement, GM agreed to expend $\$ 51.355$ million to improve vehicle and highway safety [NHTSA, 2001]. The settlement included $\$ 10$ million for research to improve fire safety of motor vehicles. In a subsequent judicial settlement, dated June 27, 1996 GM agreed to provide an additional $\$ 4.1$ million for motor vehicle fire safety research [Judicial District Court, 1996]. In the same settlement, the Class Plaintiffs' agreed to provide $\$ 1$ million for the design, development, testing, and implementation of fuel system safety enhancements for the $\mathrm{C} / \mathrm{K}$ trucks. This latter project has been administered by the Automotive Safety Research Institute and is the basis for this paper.

In September 1999, The Automotive Safety Research Institute (ASRI) initiated a research project to investigate possible alternatives to the existing sidesaddle fuel tank design that would improve the pickup truck's fuel tank crashworthiness under side impact loading conditions. To this end, Biokinetics and Associates Ltd. was contracted to identify, retrofit and test alternative fuel tank systems or tank protective strategies for the $\mathrm{C} / \mathrm{K}$ pickup trucks. A preliminary review of the existing tank designs and readily available technologies identified six possibilities, which included [Keown et al, 1999]:

1. Replacing the existing sidesaddle steel tank with a plastic tank designed specifically for the C/K trucks.

2. Adding a protective frame around the existing sidesaddle tank.

3. Installing a custom fabricated tank inside of the vehicle's frame behind the rear axle (rear mounted tank)

4. Replacing the sidesaddle tank with an auto racing fuel cell.

5. Installing a custom fabricated tank inside of the vehicle's frame forward of the rear axle (center-mounted tank).

6. Installing the OEM tank in the truck bed, behind the cab (bed mounted tank).

All six alternatives were installed in 1985 to $1987 \mathrm{C} / \mathrm{K}$ pickup trucks and subjected to the critical test condition for the sidesaddle tanks[Keown et al, 2000]. The critical test condition was an $80 \mathrm{~km} / \mathrm{h}(50 \mathrm{mph})$ side impact by a Chevrolet Caprice. Based on the favorable results obtained, the center-mounted tank and the bed-mounted tank were selected for further development and testing in other impact modes. Although the tank mounted behind the rear axle passed the critical test for sidesaddle tanks, it was not tested further due to its vulnerability to side and rear impacts directed at its location.

Three tank systems were evaluated that maintained the tank in the sidesaddle location. These were: a tank protection system, an auto racing fuel cell and an after market plastic tank. None of these succeeded at preventing fuel leakage that was below the prescribed acceptable limits when mounted on the pickup and subjected to the $80 \mathrm{~km} / \mathrm{hr}$ side impact by a Caprice.

The protective frame system that was intended to redirect impact loads around the tank to the vehicle frame was not capable of withstanding the downward moment imposed by the bumper of the impacting vehicle [Fournier et al, January 2001]. The materials of the plastic tank and the auto racing fuel cell offered insufficient resistance to damage from slashing or puncture. The auto racing fuel cell showed some promise, but was discontinued due to its higher cost [Fournier et al, November 2002]. Documentation of tests of these other technologies may be found in the Biokinetics and Associates Ltd. reports cited in the References. A summary of all tests is included in the 2003 ESV paper [Digges, 2003].

\section{TEST CONFIGURATION}

The crashworthiness of the selected tank systems was evaluated under various full-scale crash configurations. The pickup trucks used in the test were 1985 through 1987 two-wheel drive Chevrolet or GMC $1 / 2$ or $3 / 4$ ton pickups. One four-wheel drive pickup was tested. For the side impacts, the bullet vehicle was either a Chevrolet Caprice or a FMVSS 301 moving barrier. The impact speed was nominally $80.0 \mathrm{~km} / \mathrm{h}(50 \mathrm{mph})$ for the Caprice and $64.0 \mathrm{~km} / \mathrm{h}(40 \mathrm{mph})$ for the barrier. For the Caprice, the angle of impact was $60^{\circ}$ from the front of the truck and inline with a point on the truck's centerline located between the cab and the truck bed. For the FMVSS 301 rigid moving barrier, the impact was perpendicular to the longitudinal axis of the truck and centered on the space between the truck bed and the cab. The typical set-up for the side impact Caprice tests and the moving barrier side impact test are shown in Figure 1 and Figure 2.

Tests conducted with the Chevrolet Caprice as the bullet vehicle replicated as far as possible the critical vehicle to truck configurations used by the ODI during its investigation into the sidesaddle fuel tanks. This baseline test was conducted at the Vehicle Research and Test Center (VRTC) and the vehicle set-up and the test parameters were documented in Transportation Research Center Inc.'s (TRC) test report No. 930324 [Markusic, 1993].

The ride height of the bullet vehicles was adjusted to compensate for braking. VRTC had determined that under heavy braking the front of the vehicle lowered by $73.7 \mathrm{~mm}$ as measured from the front bumper centerline and the rear of the vehicle raised up by $63.5 \mathrm{~mm}$ as measured from the centerline of the rear bumper. To achieve this braking attitude a level ride was first established and then the front and rear axles were loaded and unloaded respectively to correspond to the pre-test attitude reported in TRC's Report 930324. 


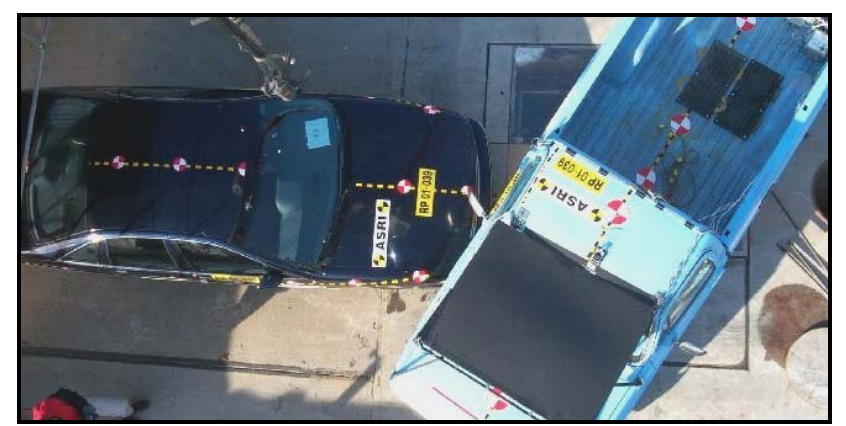

Figure 1. Typical vehicle alignment in side impact tests with a Caprice as the bullet vehicle.

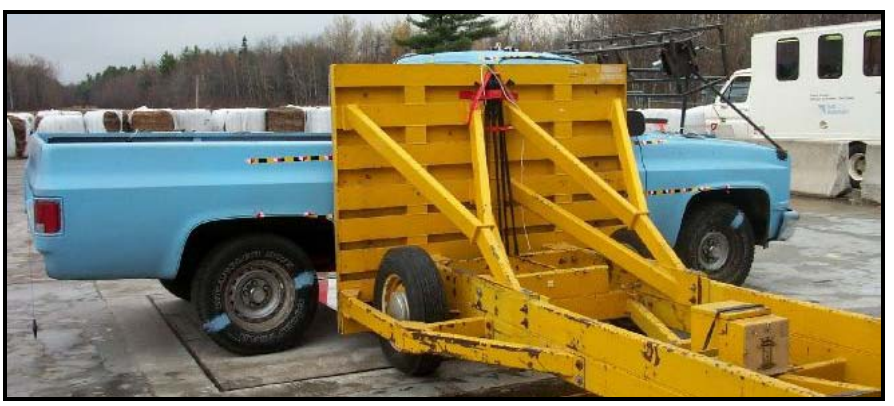

Figure 2. Alignment of the FMVSS 301 barrier for side collision.

Frontal and rear impact barrier tests were also performed following test procedures similar to those specified in the FMVSS 301 safety standard with the exception of impact speeds that at times were elevated from those specified in the standard. The three frontal barrier tests consisted of a truck colliding perpendicularly into a rigid immovable flat wall. The first of these tests was performed as per the letter of the FMVSS 301 standard with an impact speed of $49.0 \mathrm{~km} / \mathrm{h}$ (30.6 mph). The second and third frontal tests were performed at an elevated nominal speed of $51.8 \mathrm{~km} / \mathrm{h}$ (32.4 mph). Similarly, two rear barrier tests were performed with a stationary truck being struck from the rear by a moving FMVSS 301 rigid barrier at speeds of $49.0 \mathrm{~km} / \mathrm{h}$ (30.6 mph) and $56.2 \mathrm{~km} / \mathrm{h}$ (35.1 $\mathrm{mph}$ ) respectively.

\section{PASS/FAIL ASSESSMENT}

A tank system that complied with the leakage requirements specified in the FMVSS 301 standard was considered to have passed the crash test. If the post crash fuel leakage was within the specified limits, the integrity of the tank was further verified, as per the standard, by inverting the entire truck about the longitudinal axis in increments of $90^{\circ}$. The presence of leaks was again compared to the leakage limits specified in the FMVSS 301 rollover requirement. The magnitude of the allowable leakage is 28 grams (or $1.26 \mathrm{oz}$ ) per minute.

Most of the tests performed were research oriented and did not comply precisely with all the procedures set forth in the FMVSS 301 standard. For example, either the collision speed or the selection of the bullet vehicle varied from that specified by the standard. Ultimately, tests were conducted in all crash directions required by FMVSS 301, but were at higher crash severities than specified by the standard.

\section{THE BED-MOUNTED TANK}

The ODI study had concluded that the fuel tank located in the sidesaddle position results in increased risk of fuel leakage in side impact crashes. One objective of the tank relocation strategy was to install the tank in a position in which it would be less susceptible to direct loading from an impacting vehicle. By mounting a tank system in the bed of the truck, it would be both higher than typical bumper and frame heights on most vehicles and it would gain additional clearance from the side of the truck, effectively removing the tank from direct loading and avoiding undue damage. Additionally, the structure of the cab and of the bed itself would add to the protection afforded to such a system. However, such an installation reduces the capacity of the bed and limits some of its functions.

A bed-mounted tank system was installed behind the truck cab in seven GM pickup trucks. A secondary tank system was also installed on six of these trucks. The secondary tank system consisted of a custom fabricated tank installed in between the frame rails. A fuel line switching valve was installed for each truck with a secondary tank such that the truck could function from either system.

The bed-mounted system consisted of relocating a standard OEM steel tank and brackets, normally installed in the sidesaddle position, into the bed of the truck. Standard mounting brackets were used with additional holes drilled in the brackets such that they could be bolted vertically into the floor of the truck bed. A typical installation is shown in Figure 3.

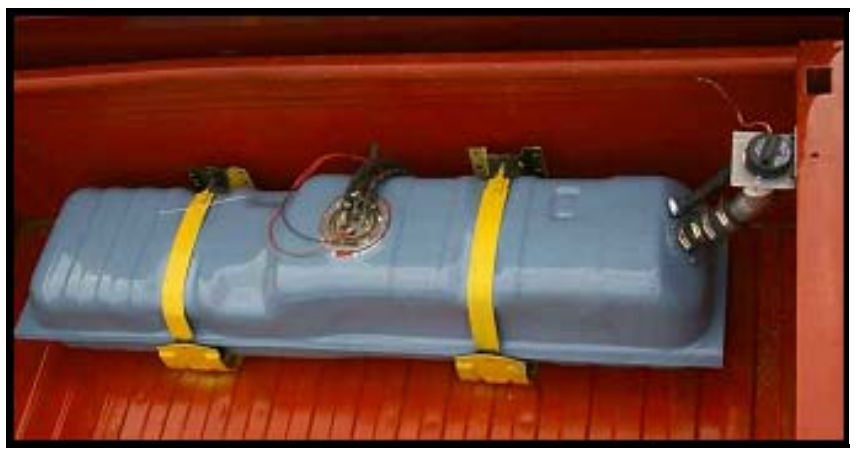

Figure 3. OEM bed tank installation with OEM brackets.

The tank was covered by a $3 \mathrm{~mm}$ thick aluminum checker plate shield for protection from shifting cargo. The shield installation is shown in Figure 4. The shield weighed $15.8 \mathrm{~kg}$ and cost approximately \$215. Other miscellaneous hardware required for the bed installation cost \$40. The installation time for the bed tank and shield was 3 hours. Installation procedures for this tank were documented in a report [Fournier et al, January 15 2003]. 


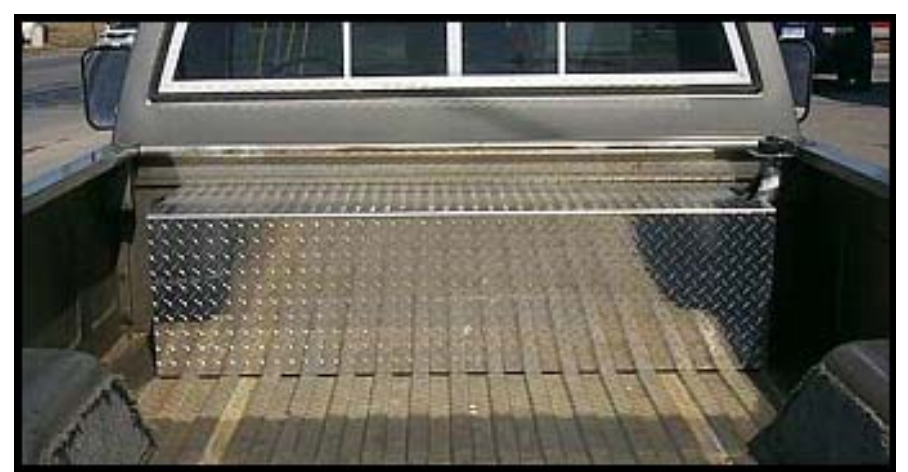

Figure 4. Typical in-bed installation of an OEM tank with shield

In some tests the tank was left exposed so that it would be visible from overhead camera views. The results of all the bed-mounted tank tests were presented in a report [Fournier February 2002] that lists the tests and shows the results. A summary of the results are presented below in Table 1

Table 1: Summary of bed-mounted tank test results

\begin{tabular}{|l|l|l|l|}
\hline Test No. & Test Type & $\begin{array}{l}\text { Speed } \\
\mathbf{( k m / h )}\end{array}$ & Results \\
\hline \hline RP01-036 & $\begin{array}{l}60^{\circ} \text { lateral impact } \\
\text { Caprice }\end{array}$ & 81.4 & Pass \\
\hline RP01-037 & $\begin{array}{l}90^{\circ} \text { lateral 301 } \\
\text { barrier }\end{array}$ & 64.2 & Pass \\
\hline RP02-028 & Frontal barrier & 49.0 & Pass \\
\hline RP02-029 & $\begin{array}{l}\text { Rear impact 301 } \\
\text { barrier }\end{array}$ & 49.0 & Pass \\
\hline RP02-031 & $\begin{array}{l}\text { Rear impact 301 } \\
\text { barrier }\end{array}$ & 56.2 & Pass \\
\hline RP02-032 & Frontal barrier & 51.8 & Pass \\
\hline 20010462 & Handling test & Na & OK \\
\hline 011024 & $\begin{array}{l}\text { Dynamic rollover } \\
\text { test }\end{array}$ & 50.2 & Pass \\
\hline
\end{tabular}

The side impact test with the Chevrolet Caprice as the bullet vehicle, as shown in Figure 1 did not challenge the tank in the bed location. The pickup damage was located below the bed of the truck, and the tank was well protected. To provide a more challenging test, an FMVSS 301 rigid faced moving barrier was used, as shown in Figure 2. However, the barrier speed was increased from $32 \mathrm{~km} / \mathrm{h}(20 \mathrm{mph})$ to $64 \mathrm{~km} / \mathrm{h}$ (40 mph). The bed-mounted tank passed this test.

Two frontal and two rear impact barrier tests were also performed following test procedures similar to those specified in the FMVSS 301 safety standard with the exception of impact speeds that at times were elevated from those specified. The two frontal barrier tests consisted of a truck colliding perpendicularly into a rigid immovable flat wall. Similarly, two rear impact tests were performed with a stationary truck being struck from the rear by a moving FMVSS 301 rigid barrier.

To verify that a truck's baseline stability and handling characteristics were not adversely affected, both a dynamic rollover test and a handling test were performed.

The rollover test was performed as per FMVSS 208. The truck was mounted on a cart at an angle of $23^{\circ}$ with the driver's side elevated such that the longitudinal axis of the truck was perpendicular to the direction of cart travel. The cart was accelerated down the test track and the truck was released and allowed to roll. The truck rolled four quarter turns. No leakage resulted from the rollover, or the subsequent static rollover performed in accordance with FMVSS 301.

An analysis of the expected change in the vertical position of a truck's CG and its influence on the Static Stability Factor (SSF) was performed. Baseline vehicle information was obtained from measurements recorded in the NHTSA's database on vehicle inertial parameters, which specified vehicle weights and the height of their CG above ground [Heydinger 1999]. Seven trucks from the database were included in the analysis, each of which had a filled sidesaddle tank installed. The cited values from the database were not corrected for the removal of the sidesaddle tank that would accompany the installation of the bed-mounted tank system.

The estimated change in the trucks' CG and SSF were calculated based on a bed-mounted tank system having a total mass of $91.0 \mathrm{~kg}$, which includes the tank, brackets, shield and 76.0 liters of fuel. The SSF was calculated according to the following formula:

$$
\mathrm{SSF}=\mathrm{T} / 2 \mathrm{H}
$$

Where,

$\mathrm{T}=$ vehicle track width

$\mathrm{H}=$ vehicle $\mathrm{CG}$ height

The static stability factor for the seven baseline trucks ranged from 1.12 to 1.25. The tank in bed filled with fuel reduced the factor by $0.7 \%$ to $1.4 \%$. An equivalent or larger change in stability factor could result from normal loading of the pickup bed with cargo.

Handling tests were performed at the Transportation Research Center (TRC) in Ohio to investigate the effect of the increase in CG height from the installation of a bed-mounted tank. A pickup truck with a bed-mounted tank and outfitted with safety outriggers was subjected to a series of four abrupt driving maneuvers by an 
experienced test driver. The purpose of these maneuvers was to evaluate the effects of fuel sloshing on vehicle stability. The four handling maneuvers included: Double Lane Change, "J" Turn, Slalom and Resonant Steer.

Initially, an empty bed-mounted tank without baffles was evaluated to provide a baseline for comparative purposes. The tank was then filled to half its capacity and finally to full capacity. An additional test was performed with the tank filled to half capacity with the inclusion of internal tank baffling.

For each handling maneuver the driver provided subjective feedback with regards to variations in the trucks handling characteristics as they related to the various tank fill levels or the inclusion of tank baffling. The driver's feedback suggested that the differences in handling were minor and were likely related to the additional fluid mass and not to fluid movement. Additionally, the driver indicated that there was no difference in handling with the introduction of tank baffling.

The relocation of the OEM tank to the pickup bed was by far the simplest alternative to the sidesaddle tank installation. It is applicable to all models of $\mathrm{GM} \mathrm{C} / \mathrm{K}$ pickup trucks and it employs a readily available tank, sending unit, mounting brackets and requires minimal modifications to the truck or tank components. The modifications consist of drilled holes in the bed floor for securing the mounting brackets and for routing the fuel lines to the engine. Additional holes are also needed in the mounting brackets for securing a simple aluminum cover to protect the tank from shifting payloads. A limitation of the system, however, is that it reduces the utility of the bed by decreasing the availability of cargo space.

\section{CENTER-MOUNTED TANK}

The chassis of the $\mathrm{C} / \mathrm{K}$ pickup trucks is basically a ladder type configuration. Two substantial longitudinal frame rails are tied together by cross members at various points along their length. By placing a tank in between these rails, a center-mounted tank system would gain protection by the rigid rails acting as a shield, diverting the load path from directly bearing on the tank. Additionally, the front end of the tank would gain extra protection from the structure of the cab and the truck bed.

The drive shaft and the exhaust system occupy the space between the frame rails. The drive shaft runs down the middle of the truck while the exhaust system is routed between the left frame rail and the drive shaft leaving the space between the right frame rail and the drive shaft available for installing a center-mounted tank.

Prior to $1982, \mathrm{C} / \mathrm{K}$ trucks were built with the fuel tank installed on the right side and with the fuel filler door located on the same side. In this configuration, connecting a center-mounted tank to the filler neck would require a fuel hose that was marginally longer than that used by the original fuel system. However, for later model years, 1982 to 1987, the fuel tank was relocated to the left side of the truck. To maintain a comparably short filler tube for the center tank, the exhaust system would have to be re-routed to the right side of the drive shaft, freeing the left side for the center tank. This was done for the first truck that was crash tested. However, this exhaust modification introduced a higher cost to the retrofit. Therefore, for the remaining trucks the center tank was installed on the right side, with the filler tube to be routed from the filler door located on the left side of the truck to the tank spout. The center-mounted tank and its associated supports are shown in Figure 5. Figure 6 and Figure 7 show the tank installed in a pickup.

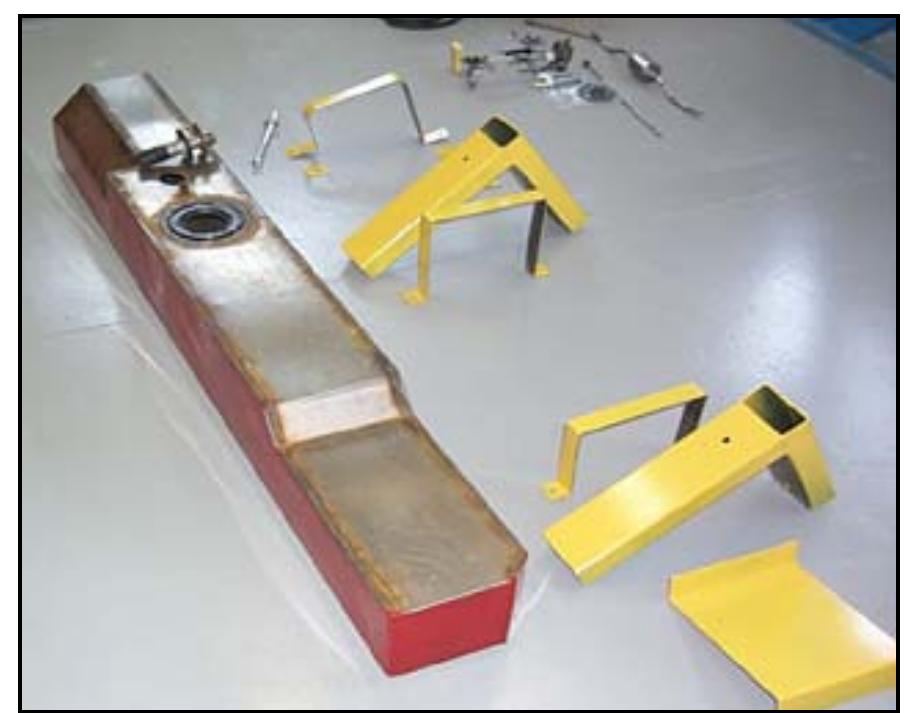

Figure 5. Center-mounted tank with mounting brackets.

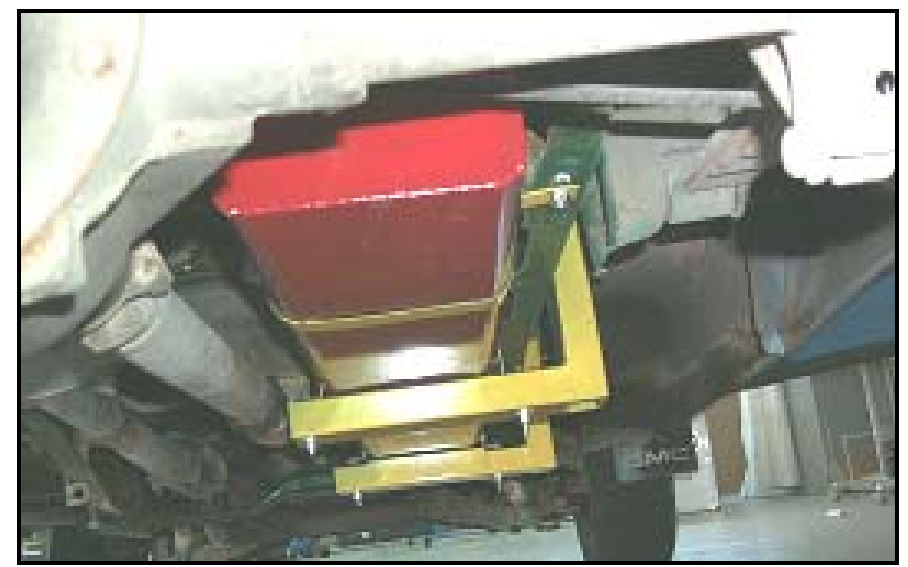

Figure 6. Typical center-mounted tank installation - rear view.

The fluid volume of the tank was 71.9 liters and its weight was $17.2 \mathrm{~kg}$. The distance between the drive shaft and the frame limited the tank width. Drive shaft to tank clearance greater than that on model year $2000 \mathrm{GM}$ pickups was maintained. Tank depth was limited by ground clearance requirements. 


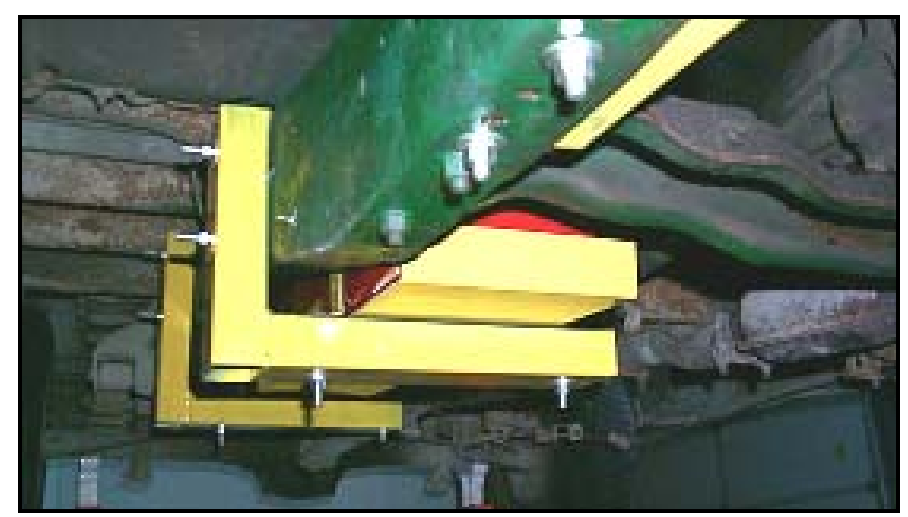

Figure 7. Typical center-mounted tank installation front view.

The center-mounted tank was custom fabricated at a welding shop specializing in fuel tanks. It comprised a box shaped container fabricated from $1.52 \mathrm{~mm}$ thick sheet steel. This steel is thicker than that used in the original equipment manufacturer's (OEM) mass produced tanks, which were nominally $0.86 \mathrm{~mm}$ thick. The reasons for the thicker steel were two fold: first, the thicker steel simplified the manual welding process and second it offered improved resistance to damage. The tank was held in place at three locations. The front and center of the tank were strapped down to a substantial "L" shaped bracket that bolted directly to a frame rail and supported the tank from underneath (See Figure 6 and Figure 7). A strap that attached to the frame rail and a cross member supported the rear of the tank. The weight of the straps, brackets and miscellaneous components was $12.1 \mathrm{~kg}$. Approximately three hours of labor was required to install the tank. Installation procedures for the center-mounted tank were documented in a report [Fournier et al, January 29, 2003].

Eleven full-scale crash tests on the GM C/K trucks were conducted at PMG Technologies' Test and Research Center in Blainville, Quebec, Canada. The sequence of tests and their configurations and the overall success of the tests are summarized in a report [Fournier et al, October 2001].

All of the tests involving the Chevrolet Caprice as the bullet vehicles were conducted under identical conditions. These tests duplicated the $80.0 \mathrm{~km} / \mathrm{h}$ $(50.0 \mathrm{mph}) 60^{\circ}$ tests conducted by NHTSA during their defects investigation program.

A characteristic of each Caprice test was that upon impact the truck was lifted off the ground and carried laterally a short distance before the truck tires came back in contact with the ground. Both vehicles continued moving before coming to rest, typically with the Caprice wedged under the side of the truck. In the initial test, the truck rolled one quarter turn after the impact. The fuel leakage following this dynamic rollover and the subsequent static rollover was less than permitted by FMVSS 301. This test demonstrated the integrity of the fuel system in both side impact and rollover. Subsequent tests incorporated anti-roll bars to prevent rollover after the impact.

The final tank design demonstrated the ability to withstand the $80.0 \mathrm{~km} / \mathrm{h}$ (50 mph) Chevrolet Caprice side impact that had been the critical test condition for the OEM tank. In addition, the tank design was tested to and passed front, side and rear impacts more severe than required by FMVSS 301 . The test results are summarized in Table 2.

Table 2: Summary of center-mounted tank test results.

\begin{tabular}{|c|c|c|c|c|}
\hline \multirow[t]{2}{*}{ Test No. } & \multirow[t]{2}{*}{ Test Type } & \multirow{2}{*}{$\begin{array}{l}\text { Speed } \\
(\mathrm{km} / \mathrm{h})\end{array}$} & \multicolumn{2}{|c|}{ Results } \\
\hline & & & Tank & Lines \\
\hline RP01-009 & $\begin{array}{l}60^{\circ} \text { side } \\
\text { impact by a } \\
\text { Caprice }\end{array}$ & 81.6 & Pass & Pass \\
\hline RP01-036 & $\begin{array}{l}60^{\circ} \text { side } \\
\text { impact by a } \\
\text { Caprice }\end{array}$ & 81.4 & Pass & Fail $^{(1)}$ \\
\hline RP 01-037 & $\begin{array}{l}90^{\circ} \text { side } \\
\text { impact by a } \\
301 \text { barrier }\end{array}$ & 64.2 & Pass & Pass \\
\hline RP 01-038 & $\begin{array}{l}60^{\circ} \text { side } \\
\text { impact by a } \\
\text { Caprice }\end{array}$ & 81.4 & Fail $^{(2)}$ & Fail $^{(2)}$ \\
\hline RP 01-039 & $\begin{array}{l}60^{\circ} \text { side } \\
\text { impact by a } \\
\text { Caprice }\end{array}$ & 81.4 & Pass & Pass \\
\hline RP 02-028 & $\begin{array}{l}\text { Frontal } \\
\text { barrier }\end{array}$ & 49.0 & Pass & Pass \\
\hline RP 02-029 & $\begin{array}{l}\text { Rear } \\
301 \text { barrier }\end{array}$ & 49.0 & Pass & Pass \\
\hline RP 02-030 & $\begin{array}{l}60^{\circ} \text { side } \\
\text { impact by a } \\
\text { Caprice } \\
\text { (4x4 truck) }\end{array}$ & 80.0 & Pass & Pass \\
\hline RP 02-031 & $\begin{array}{l}\text { Rear } \\
301 \text { barrier }\end{array}$ & 56.2 & Pass & Pass \\
\hline RP 02-032 & $\begin{array}{l}\text { Frontal } \\
\text { rigid barrier }\end{array}$ & 51.8 & Fail $^{(3)}$ & Pass \\
\hline RP 02-096 & $\begin{array}{l}\text { Frontal } \\
\text { rigid barrier }\end{array}$ & 51.8 & Pass & Pass \\
\hline
\end{tabular}

(1)No tank leakage; fuel line switching valve crushed.

(2)Truck tested with manifold removed - reduced inherent protection. Induced tank and fuel line improvements.

(3)Transmission web caused stress concentration. Induced a tank improvement.

The design of the center-mounted tank and its associated mounting brackets evolved based on information gained during the test program, incorporating features to improve its crashworthiness. The early design is shown in Figure 8. The tank was fabricated by welding together steel plates that formed the top, bottom, sides and ends of the tank. Side crash tests suggested several design improvements. The most 
significant was the elimination of the welded seams for the bottom tank plate. Severe crimping occurred at the corner seams in Test 038, resulting in a small leak.

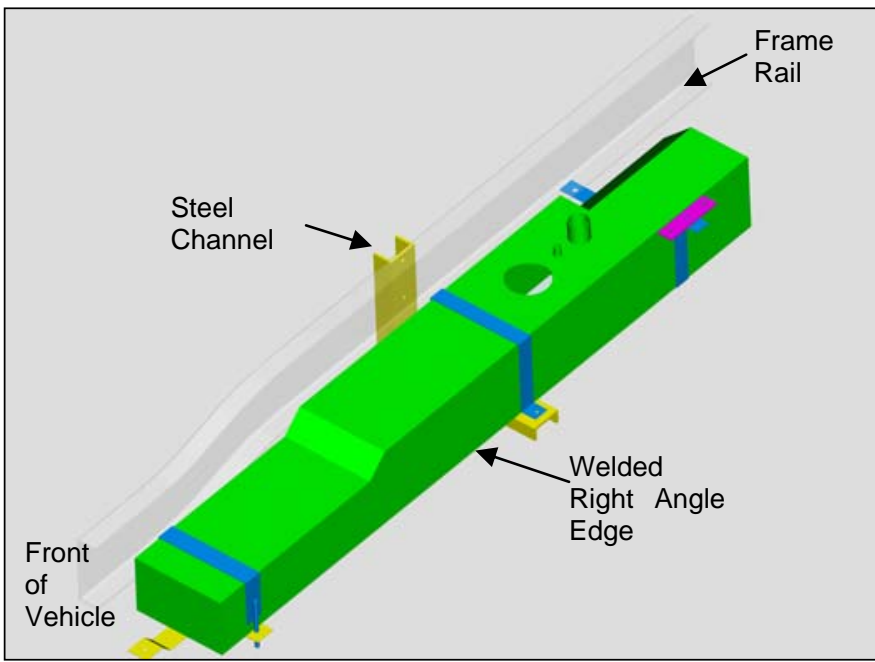

Figure 8. Early configuration of center-mounted tank and supports.

From the fourth test (039) onwards, the tank was modified so that the bottom and two sides were formed from a single plate. A $25.4 \mathrm{~mm}$ radius to the lower longitudinal edges of the tank was maintained. The purpose of the radius was to reduce localized stress resulting from folding a right angle edge in on itself when loaded. Additionally, the material for the middle bracket was changed from steel channel with right angle edges to steel tubing with rounded and thus less aggressive edges. Loading on the tank from these brackets would therefore be more evenly distributed, decreasing the possibility of tearing of the tank from concentrated edge loads from the brackets. The resulting design is shown in Figure 9.

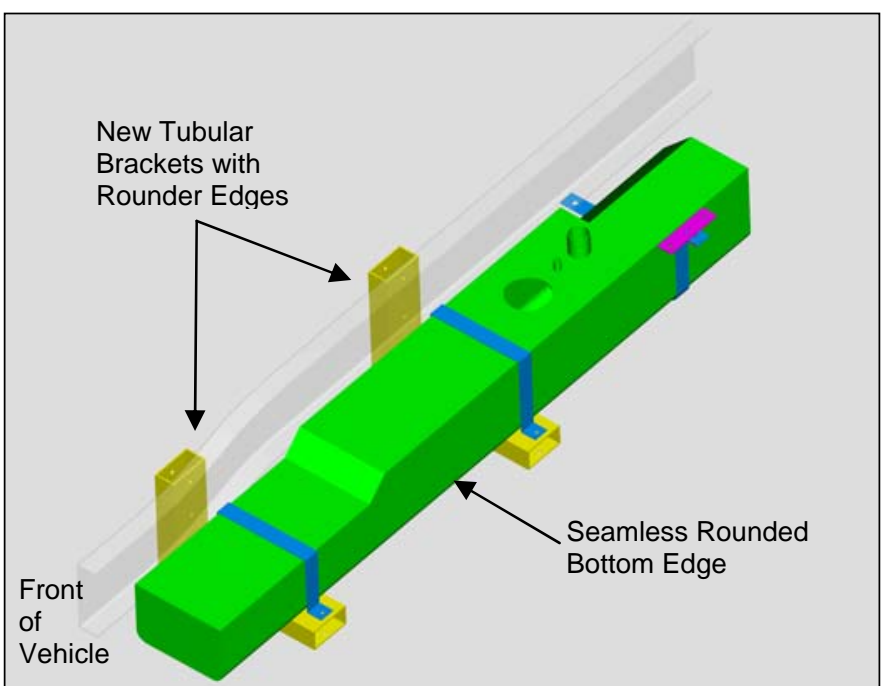

Figure 9. Modifications to improve side-impact protection.

During frontal impact testing, it was discovered that the tank shifted forward excessively upon impact. The OEM steel tanks are fabricated using a forming process that can incorporate recesses for the mounting straps that aid in preventing sliding. The flat sides of the custom tanks allowed movement of the tank through the mounting brackets' straps. This deficiency was overcome by increasing the clamping pressure of the mounting straps and by adding a tank catch plate at the front. One end of the plate was bent down to hook onto the front tank support bracket. The other end of the plate was bent upwards to prevent the tank from undergoing excessive translation. This plate was sandwiched in place between the front bracket and the tank.

In addition, it was observed that the transmission moved rearward during a severe frontal crash. One of the transmissions available in the pickups contained a flange that could cause a stress concentration if it impacted the tank corner. To address this possibility, the tank corner closest to the transmission was modified to include a flattened region as shown in Figure 10.

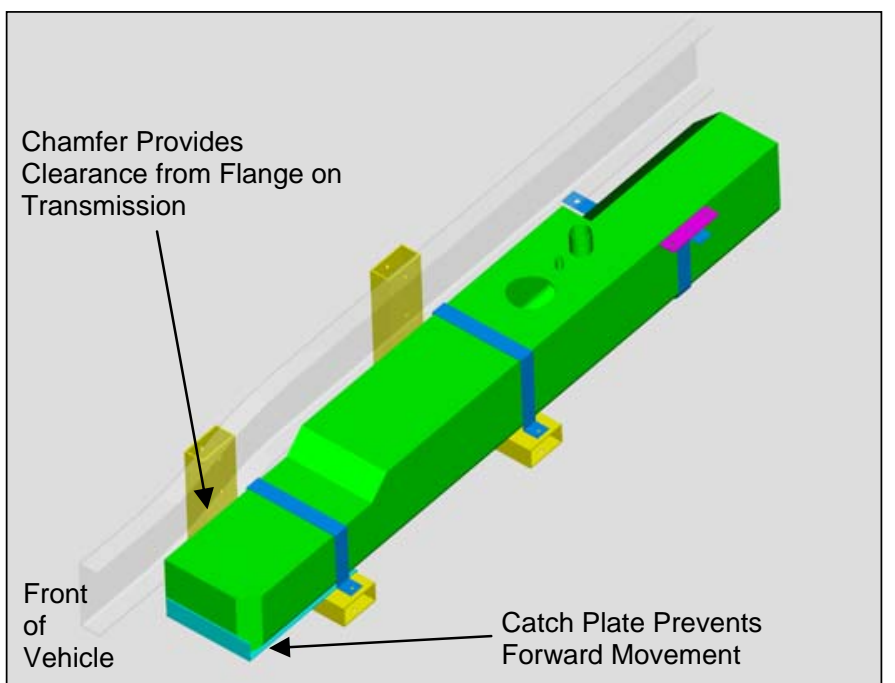

Figure 10. Modifications to Improve frontal- impact protection

Various fuel tank components other than the tank itself were evaluated during different tests. They included a plastic shield under the tank, a filler tube check valve and an after market sending unit. The plastic shield provided additional protection to the bottom and both sides of the tank. However, the tank was also tested without the shield and performed satisfactorily. On many of the tanks tested a reverse flow check valve was installed. In the event that the fuel filler tube was severed or torn from the tank, the check valve would prevent excessive fuel spillage. The diameter of the check valve obtained for testing was smaller than the filler hose, which resulted in a flow restriction that increased the time needed to fill the tank. The functionality of these valves was never required, as the filler tube remained intact and connected to the tank during all the tests. However, this feature is standard on most present day vehicles and is a recommended upgrade. 


\section{FEATURES TO ADDRESS HAZARDS IN THE CENTER-MOUNTED TANK LOCATION}

\section{Vulnerability from Transmission and Drive Shaft}

Relocating the tank between the frame rails reduces its vulnerability to side impact, but may increase vulnerability in some other crashes. In severe crashes into a rigid frontal barrier the engine and transmission move rearward. An aggressive web on one of the alternative transmission produced a leak in one frontal barrier test. In addition, the drive shaft may buckle in the direction of the tank causing damage. Figure 11 shows the location of the aggressive transmission web and the drive shaft relative to the tank before and after a frontal crash test. a)

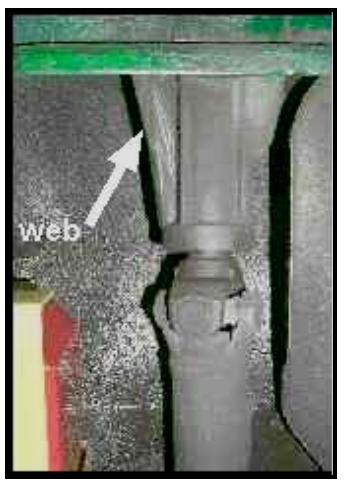

Pre-test b)

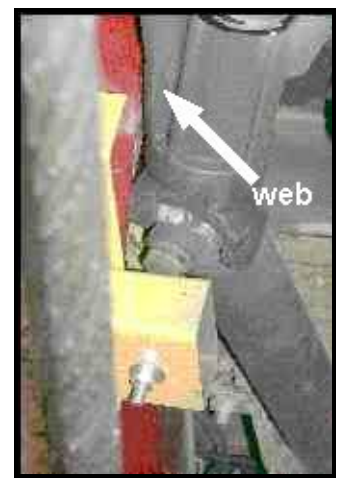

Post-test
Figure 11. Drive shaft and transmission clearance in severe frontal crash - before (a) and after (b).

The final center-mounted tank design addressed both of these undesirable loadings. The transmission contact was mitigated by increasing the tank to transmission clearance and by chamfering the corner of the tank to reduce the stress concentration when contact occurs. The drive shaft contact was addressed by maintaining OEM drive shaft clearance for center-mounted tanks and by positioning the tank brackets to resist drive shaft loading. The tank thickness of $1.52 \mathrm{~mm}$ provided added protection compared with $0.86 \mathrm{~mm}$ in the OEM tank.

\section{$\underline{\text { Protection of Fuel Lines and Fuel Selector Valve }}$}

The Caprice impact produced extensive deformation to the pickup frame. In some cases, the fuel lines and/or fuel tank selector valves were severed by being pressed between the inside of the frame and the engine. This problem was aggravated in one test in which the exhaust manifold had been removed. In that test, the fuel line was severed when entrapped between the frame and a flange on the transmission. To improve the survivability of fuel lines, a structural shield was added inside the frame to protect the fuel filter. The shield is shown in Figure12. No fuel line ruptures occurred on tests with the shielding in place.

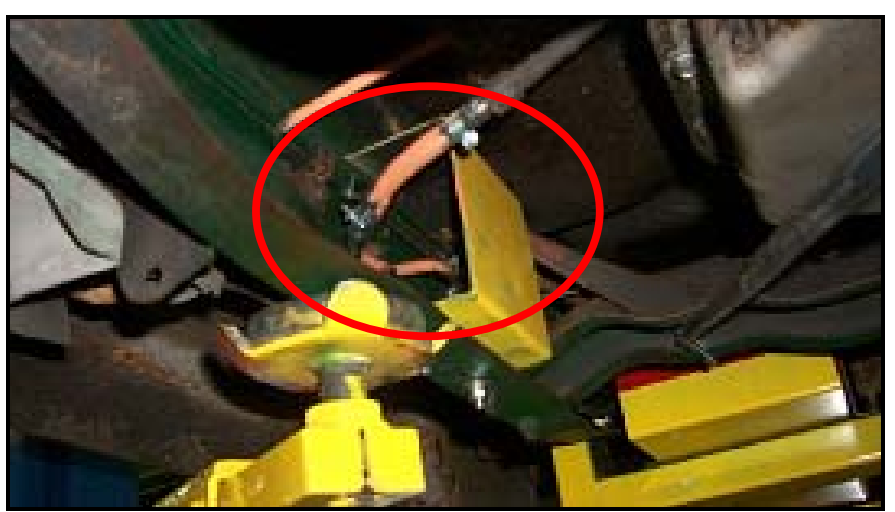

Figure 12. Shielding plate to protect fuel lines from entrapment by the transmission.

\section{Protection From Hard Points on the Bullet Vehicle}

It was found that the front hood of the bullet Caprice was peeled away in the side impact tests. As a result, many sharp edges were exposed. In addition, the battery, electrical wiring, and hot engine surfaces were exposed providing possible ignition sources. Figure 13 shows the protruding alternator and other sharp edges that scraped the bottom of the pickup tank in a crash test. For the center-mounted tank, the hard points resulted in scrapping and minor gouging of the tanks. However, no leakage occurred from this source in any tests of the center-mounted tank.

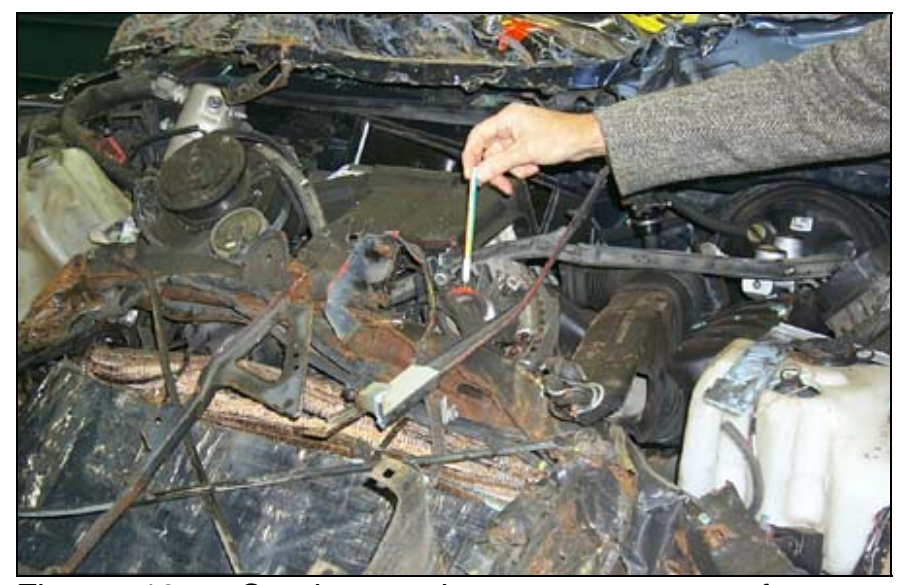

Figure 13. Caprice engine compartment after test showing hard points that contacted the fuel tank.

In one test of the center-mounted tank a plastic shield was installed so that it covered the bottom and sides of the tank. During the test, the shield remained securely in place and provided additional protection from hard points on the impacting vehicle. The metal thickness of the center-mounted tank proved to be adequate to resist the contacts with the hard points on the Chevrolet Caprice, so the shield was not tested further. Notwithstanding the benefits of the shield in a crash environment, the shield would also provide protection from wear and tear caused by typical road hazards (i.e. rocks and dirt). 


\section{SUMMARY AND CONCLUSIONS}

Seventeen full-scale crash tests were performed on six alternatives to the sidesaddle tanks on 1973 to 1987 GM $\mathrm{C} / \mathrm{K}$ pickup trucks. The critical test configuration was an $80.0 \mathrm{~km} / \mathrm{h}$ (50 mph) lateral impact from a Chevrolet Caprice. Two alternative tank systems were selected for further test and evaluation. The evaluation included FMVSS 301 frontal, rear and lateral type tests conducted at higher severity than required by FMVSS 301.

The center-mounted tank and the bed-mounted tank improved crashworthiness through relocation of the tank. In the center-mounted location, the tank was removed from direct loading and additional protection was afforded by the vehicle's frame rail. Additional tank features, such as rounded and chamfered corners, were incorporated in the center tank design to enhance its resistance to damage. The bed-mounted tank system consisted primarily of standard OEM components relocated to the bed of the truck. Both systems performed exceptionally well under the severe crash conditions of the test program.

In general, the most effective means of improving the tank's crashworthiness was by positioning it so that direct loading is minimized or avoided altogether. The same strategy was applied to the other fuel system components, such as, fuel lines and tank selection valves for multi-tank systems. The shielding of the fuel lines provided a remedy for the fuel line crushing experienced during testing.

\section{ACKNOWLEDGEMENT}

The authors would like to recognize that funding for this research was established by the Class Plaintiff's as part of the White, Monson and Cashiola vs. General Motors Settlement Agreement. The crash testing under this project was conducted by PMG Technologies, and TRC Inc. The professionalism and attention to detail of both staffs is acknowledged and appreciated.

All reports and videos of the tests referenced in this paper are available from the FHWA/NHTSA National Crash Analysis Center at The George Washington University.

\section{REFERENCES}

1. Digges, K., Fournier, E., Keown, M., Shewchenko, $\mathrm{N}$, and Kot, J., "Research to Evaluate Safety Technologies for Vulnerable Fuel Tanks", ESV paper 230, Proceedings of $15^{\text {th }}$ International ESV Conference, May, 2003.

2. Fournier, E., Keown, M., "Summary Report: Tank Protection System for GM 1500 series Pickup Trucks", Biokinetics and Associates Ltd., Ottawa, Canada, Biokinetics Report R00-28b, January 17, 2001.
3. Fournier, E., Keown, M., Kot, J., Bayne, T., "Summary Report: Centre Mounted Tank System for the GM C/K 1500 Pickup Trucks", Biokinetics and Associates Ltd. Report no. R01-02c, October 2001.

4. Fournier, E.,"Summary Report: Bed Mounted Tank System for GM 1500 Pickup Trucks", Biokinetics and Associates Ltd. Report no. R01-03c, February 22, 2002.

5. Fournier, E., Kot, J.,"Side Impact Tests of GM 1500 Series Pickups Retrofitted With An Auto Racing Fuel Cell", Biokinetics and Associates Ltd., Ottawa, Canada, Biokinetics Report R02-15, November 15, 2002.

6. Fournier, E., Kot, J., Keown, M., "Installation of a Box Mounted Tank in the GM C/K 1500 Pickup Truck", Biokinetics and Associates Ltd. Report no. R01-20c, January 15, 2003.

7. Fournier, E., Kot, J., "Installation of a Centre Mounted Tank in the GM C/K 1500 Pickup Truck", Biokinetics and Associates Ltd. Report no. R01-21b, January 29, 2003.

8. Keown, M., Kot, J., Shewchenko, N., Fournier, E., "GM C/K Pickup Truck Fuel Tank Retrofit Evaluation, Phase 1", Biokinetics and Associates Ltd., Ottawa, Canada, Biokinetics Report R99-13, December 20, 1999.

9. Keown, M., Fournier, E., "Activity Report: Retrofit Fuel Tank System Testing", Biokinetics and Associates Ltd., Ottawa, Canada, Biokinetics Report R00-16, September 20, 2000.

10. Heydinger, G. J., Bixel, R. A., Garrott, W. R., Pyne, M., Howe, J. G., Guenther, D. A., "Measured Vehicle Inertial Parameters - NHTSA's Data Through November 1998, SAE paper 1999-01-1336, 1999.

11. Judicial District Court "Agreement of Settlement, White, Monson and Cashiola vs. General Motors", Number 42,865, DIV."D", $18^{\text {th }}$ Judicial District Court, Parish of Iberville, Louisiana, June 27, 1996.

12. Markusic, C., "Final Report of 1991 Chevrolet Caprice into a 1986 Chevrolet C10 Pickup Truck", Transportation Research Centre Inc., Final Report, No. 930324, March 1993.

13. National Highway Traffic Safety Administration, Federal Motor Vehicle Safety Standard, Part 571.301 "Standard No. 301; Fuel system integrity".

14. National Highway Traffic Safety Administration, "U.S. DoT/General Motors Settlement Agreement Status Report, Year 4", NHTSA 2001

15. Office of Defects Investigation, "Engineering Analysis Report and Initial Decision That The Subject Vehicles Contain A Safety Related Defect", National Highway Traffic Safety Administration, Engineering Analysis EA92-041, October 17, 1994. 